\title{
PENGARUH OFFICE CHANNELING DAN DANA PIHAK KETIGA TERHADAP LABA DENGAN PEMBIAYAAN SEBAGAI VARIABEL INTERVENING PADA PERBANKAN SYARIAH DI INDONESIA
}

\author{
Muhammadinah \\ Universitas Islam Negeri Raden Fatah Palembang \\ Email: muhammadinah_uin@radenfatah.ac.id
}

\begin{abstract}
This research aims to determine the influence of Office Channeling and third party funds to profit with financing as a variable intervening on sharia banking in Indonesia. The population in this study is all sharia banking in Indonesia consisting of 14 BUS and 20 UUS. Then the sample used is the summary of Sharia banking financial statements in the period of 3 years on a monthly basis so that the number of samples as much as $12 \times 3=36$. The analytical technique used is Path analysis using Test $\mathrm{T}$, the mediation test is done with Sobel Test. The research results show that: a) the Office Channeling variable is directly influential and insignificant to the financing variable. $b$ ) The variables of the third party fund are directly influential and significant to the financing variable. c) The variable Office Channeling is directly influential and significant to the profit variable. d) Variable third party funds are directly influential and insignificant to the profit variable. e) The financing variable is directly influential and significant to the profit variable. $f$ ) The financing variable is not able to view the influence of the Office Channeling variable on profit variable. g) The financing variable is capable of imradiation the influence of third-party funds variables to profit variables.
\end{abstract}

Keywords: Office Channeling, third party fund, profit, financing 


\begin{abstract}
Abstrak
Penelitian ini bertujuan untuk mengetahui pengaruh Office Channeling dan Dana Pihak Ketiga terhadap Laba dengan Pembiayaan sebagai variabel intervening pada Perbankan Syariah di Indonesia. Populasi dalam penelitian ini adalah seluruh Perbankan Syariah di Indonesia yang terdiri dari 14 BUS dan 20 UUS. Kemudian sampel yang digunakan yaitu rangkuman laporan keuangan Perbankan Syariah kurun waktu 3 tahun secara bulanan sehingga jumlah sampel sebanyak $12 \times 3=36$. Teknik analisis yang digunakan adalah analisis jalur (Path Analysis) dengan menggunakan uji $t$, pengujian mediasi dilakukan dengan Sobel Test. Hasil penelitian menunjukkan bahwa: a) variabel Office Channeling secara langsung berpengaruh dan tidak signifikan terhadap variabel Pembiayaan. b) variabel Dana Pihak Ketiga secara langsung berpengaruh dan signifikan terhadap variabel Pembiayaan. c) variabel Office Channeling secara langsung berpengaruh dan signifikan terhadap variabel Laba. d) variabel Dana Pihak Ketiga secara langsung berpengaruh dan tidak signifikan terhadap variabel Laba. e) variabel Pembiayaan secara langsung berpengaruh dan signifikan terhadap variabel Laba. f) variabel Pembiayaan tidak mampu memediasi pengaruh variabel Office Channeling terhadap variabel Laba. g) variabel Pembiayaan mampu memediasi pengaruh variabel Dana Pihak Ketiga terhadap variabel Laba.
\end{abstract}

Kata Kunci: Office Channeling, Dana Pihak Ketiga, Laba, Pembiayaan 


\section{PENDAHULUAN}

Indonesia adalah Negara dengan penduduk muslim terbesar di dunia. Mayoritas penduduk yang beragama Islam menjadikan Indonesia sebagai pasar yang potensial dalam pengembangan keuangan syariah. Salah satu yang saat ini sudah mulai berkembang dengan pesat yaitu adalah dengan adanya bank-bank yang kegiatan operasionalnya menggunakan prinsip syariah. Institusi perbankan syariah ini mulai merata dan menampakkan jati dirinya ditengah-tengah banyaknya bank-bank konvensional yang ada.

Bank-bank syariah di Indonesia mulai mengupayakan peningkatan kualitas layanan agar dapat sejajar dengan bank-bank konvensional. Akses teknologi informasi seperti ATM, mobile banking maupun internet banking menjadi fokus bagi pengembangan kualitas layanan dari bank-bank syariah.

Ada beberapa faktor yang menjadi penghambat berkembangnya industry perbankan syariah di Indonesia, antara lain: belum memadainya sumber daya manusia yang terdidik dan profesional, menyangkut manajemen sumber daya manusia dan pengembangan budaya serta jiwa wirausaha (entrepreneurship) bangsa kita yang masih lemah, permodalan (dana) yang relatif kecil dan terbatas, adanya ambivalensi antara konsep syariah pengelolaan bank syariah dengan operasionalisasi di lapangan, tingkat kepercayaan yang masih rendah dari umat Islam dan secara akademik belum terumuskan dengan sempurna untuk mengembangkan lembaga keuangan syariah dengan cara sistematis dan proporsional. Kompleksitas persoalan tersebut menimbulkan dampak terhadap kepercayaan masyarakat tentang keberadaan bank syariah di antara lembaga keuangan konvensional (Aam Slamet Rusydiana, 2016)

Permasalahan selanjutnya adalah perkembangan bank syariah di Indonesia terkesan agak lambat karena kurang dikelola secara profesional. Kurang berkembangnya bank syariah terletak pada umatnya sendiri, karena masih ada umat Islam belum paham ekonomi Islam ataupun tidak mempraktekkanya dalam bertransaksi bisnis dan keuangan sehari-hari, merasa takut menjadi miskin karenanya (Fitri, 2014).

Dalam rangka mempercepat perkembangan perbankan syariah, Bank Indonesia menyempurnakan kebijakan pengembangan jaringan layanan syariah melalui Layanan Syariah (LS)/Office Channeling (OC). Langkah ini dilaksanakan melalui penerbitan Peraturan Bank Indonesia (PBI) No. 9/7/PBI/2007 tanggal 4 Mei 2007 tentang Perubahan Atas Peraturan Kegiatan Usaha Bank Umum Konvensional Menjadi Bank Umum yang Melaksanakan Kegiatan Usaha Berdasarkan Prinsip Syariah dan Pembukaan Kantor Bank yang Melaksanakan Kegiatan Usaha Berdasarkan Prinsip Syariah oleh Bank Umum Konvensional. 
Melalui Peraturan Bank Indonesia tersebut mengizinkan bank-bank membuka layanan syariah dengan office channeling. Artinya, setiap kantor bank diperbolehkan membuka layanan syariah, tanpa harus membuka kantor cabang sendiri yang tentunya membutuhkan biaya yang tidak kecil.

Kebijakan sistem office channelling ini, salah satunya meningkatkan layanan yang semula hanya melakukan kegiatan penghimpunan dana, diperluas dengan melakukan seluruh transaksi perbankan yaitu penghimpunan dan penyaluran dana serta jasa transaksi perbankan syariah lainnya yang diharapkan akan berdampak pada peningkatan laba Bank Syariah.

Pada sistem office channelling adanya kegiatan penghimpunan dana dapat meningkatkan Dana Pihak Ketiga (DPK). Sumber dana dari dana pihak ketiga (DPK) yang dihimpun merupakan dana terbesar yang paling diandalkan oleh pihak bank dari seluruh dana yang dikelola oleh bank. Setiap kenaikan dana pihak ketiga dapat meningkatkan jumlah dana yang disalurkan kepada masyarakat (Dendawijaya, 2009).

Pembiayaan merupakan fungsi bank dalam menjalankan fungsi penggunaan dana. Dalam kaitan dengan bank maka ini merupakan fungsi yang terpenting. Dari pembiayaan yang dikeluarkan atau disalurkan bank diharapkan dapat mendapatkan hasil. Tingkat penghasilan dari pembiayaan (yield on financing) merupakan tingkat penghasilan tertinggi dari bank. Pembiayaan yang disalurkan oleh pihak bank terhadap deposan akan memberikan konstribusi terhadap peningkatan.

Penelitian yang dilakukan oleh Yashinta Putri Aliza dan Eni Wuryani (2019) dimana hasil penelitiannya menunjukkan office channeling berpengaruh terhadap kinerja keuangan Unit Usaha Syariah (UUS) di Indonesia.

Penelitian yang dilakukan oleh Luhur Prasetiyo (2012) dimana hasil penelitiannya menunjukkan bahwa setelah disahkannya UU No. 21 tahun 2008 tentang Perbankan Syariah dengan diberlakukannya office channeling perkembangan jumlah Bank Umum Syariah (BUS) selama 3 tahun pra UUPS mengalami pertumbuhan 66\%, asset bank syariah meningkat sebesar $137 \%$, kemudian total pembiayaan bank syariah dari 15 triliun rupiah meningkat menjadi 38 triliun rupiah.

Berdasarkan uraian di atas, peneliti merasa tertarik untuk melakukan penelitian ini untuk mengetahui apakah kebijakan yang diberikan oleh Bank Indonesia mampu mengatasi beberapa permasalahan yang dihadapi oleh Perbankan Syariah di Indonesia. 


\section{LANDASAN TEORITIS}

\section{Office Channeling}

Office Channelling adalah istilah yang digunakan Bank Indonesia (BI) untuk menggambarkan penggunaan kantor bank konvensional dalam melayani transaksitransaksi syariah, dengan syarat bank yang bersangkutan telah memiliki Unit Usaha Syariah (UUS), seperti Bank BNI Syariah, BRI Syariah, Bank Sumut Syariah, dan lainlain. Dengan demikian, masyarakat dapat menabung dan mendepositokan uangnya secara syariah di bank konvensional yang memiliki UUS tersebut, sehingga tidak harus datang ke kantor cabang bank syariah.

Menurut pasal 1 ayat 20 Peraturan Bank Indonesia No.8/3/2006 menerangkan bahwa: “ Layanan Syariah adalah kegiatan penghimpunan dana yang dilakukan di kantor cabang dan atau dibawah kantor cabang untuk dan atas nama Kantor Cabang Syariah pada Bank yang sama"

Dalam peraturan PBI No.8/3/2006 tentang Layanan Syariah yang kemudian disebut dengan Office Channelling (OC), yaitu perubahan kegiatan usaha bank konvensional menjadi bank syariah dan pembukaan kantor syariah oleh bank konvensional, dengan kata lain cabang bank konvensional yang telah memiliki UUS (Unit Usaha Syariah) diperbolehkan menerapkan layanan syariah. Dalam PBI No.9/2006 yang merupakan revisi PBI No.8/3/2006 Layanan Syariah adalah kegiatan penghimpunan dana, pembiayaan dan pemberian jasa perbankan lainnya berdasarkan prinsip syariah yang dilakukan di Kantor Cabang dan atau di Kantor Cabang Pembantu, untuk dan atas nama Kantor Cabang Syariah pada Bank yang sama

\section{Dana Pihak Ketiga}

Undang-Undang Nomor 10 Tahun 1998 tentang Perbankan (UU Perbankan) nenjelaskan bahwa Dana Pihak Ketiga (DPK) adalah dana yang dipercayakan oleh masyarakat kepada bank berdasarkan perjanjian penyimpanan dana dalam bentuk giro, deposito, sertifikat deposito, tabungan, atau bentuk lainnya yang dipersamakan dengan itu.

Menurut UU Perbankan ini, sumber dana yang dimaksud dapat berupa:

1. Giro yaitu simpanan yang penarikannya dapat dilakukan setiap saat dengan menggunakan cek, bilyet giro, sarana perintah pembayaran lainnya atau dengan cara pemindahbukuan.

2. Deposito yaitu simpanan yang penarikannya hanya dilakukan pada waktu tertentu berdasarkan perjanjian nasabah penyimpan dengan bank. 
3. Tabungan adalah simpanan yang penarikannya hanya dapat dilakukan menurut syarat-syarat tertentu yang disepakati, tetapi tidak dapat ditarik dengan cek, bilyet giro, dan atau alat lainnya.

\section{Laba}

Laba bersih merupakan selisih positif atas penjualan dikurangi biaya-biaya dan pajak. Pengertian laba yang dianut oleh organisasi akuntansi saat ini adalah laba akuntansi yang merupakan selisih positif antara pendapatan dan biaya. Laba merupakan kelebihan total pandapatan dibandingkan total bebannya, disebut juga pendapatan bersih atau net earning. Laba bersih adalah laba operasi dikurangi pajak, biaya bunga, biaya riset, dan pengembangan. Laba bersih disajikan dalam laporan rugi-laba dengan menyandingkan antara pendapatan dengan biaya (Muhammad, 2008).

Ada banyak faktor yang mempengaruhi perubahan laba bersih (net income), diantaranya yaitu (Jumingan, 2011:165):

1. Naik turunnya jumlah unit yang dijual dan harga jual per unit;

2. Naik turunnya harga pokok penjualan, di mana harga pokok ini dipengaruhi oleh jumlah unit yang dibeli atau diproduksi atau dijual dan harga pembelian per unit atau harga pokok per unit;

3. Naik turunya biaya usaha yang dipengaruhi oleh jumlah unit yang dijual, variasi jumlah unit yang dijual, variasi dalam tingkat harga dan efisiensi operasi perusahaan;

4. Naik turunnya biaya pos penghasilan atau biaya non-operasional yang dipengaruhi oleh variasi jumlah unit yang dijual, variasi dalam tingkat harga danperubahan kebijakan dalam pemberian atau penerimaan discount;

5. Naik turunnya pajak perseroan yang dipengaruhi oleh besar kecilnya laba yang diperoleh atau tinggi rendahnya tarif pajak;

6. Adanya perubahan dalam metode akuntansi

\section{Pembiayaan}

Menurut UU No. 10 tahun 1998 tentang perbankan menyatakan pembiayaan adalah penyediaan uang atau tagihan yang dipersamakan dengan itu berdasarkan persetujuan atau kesepakatan antara bank dengan pihak lain yang mewajibkan pihak yang dibiayai untuk mengembalikan uang atau tagihan tersebut setelah jangka waktu tertentu dengan imbalan atau bagi hasil

Menurut Binti, Nur Asiyah (2014) pembiayaan bertujuan untuk: 
1. Makro

a. Peningkatan ekonomi umat, artinya masyarakat yang tidak dapat akses secara ekonomi dapat melakukan pembiayaan untuk mencukupi ekonomi;

b. Tersdianya dana bagi peningkatan usaha;

c. Meningkatkan produktivitas;

d. Membuka lapangan kerja baru yang artinya dengan dibukanya sektor-sektor usaha melalui penambahan dana pembiayaan maak sektor usaha tersebut akan menyerap tenaga kerja

e. Terjadinya distribusi pendapatan.

2. Mikro

a. Upaya untuk memaksimalkan laba;

b. Upaya meminimalkan risiko kekurangan modal;

c. Pendayagunaan sumber ekonomi

d. Penyaluran kelebihan dana

Dalam kaitan profitabilitas dan keamanan bank, bank syariah cenderung memberikanpembiayaan kepada nasabah yang memiliki tingkat kemampuan bayar, dan juga nasabah yang berpeluang memberikan keuntungan terhadap bank. Kecuali dalam kondisi tertentu, misalnya dalam rangka memaksimalkan dana yang terserap, maka Bank Syariah tidak terlalu berfikir untuk mendapatkan keuntungan langsung yang besar dari masyarakat, melainkan bagaimana volume pembiayaan yang besar. Dengan demikian diharapkan oleh bank akan juga memberikan akumulasi keuntungan yang besar terhadap bank (Binti, Nur Asiyah, 2014).

\section{METODE}

Populasi dalam penelitian ini adalah seluruh Perbankan Syariah di Indonesia yang terdiri dari 14 Bank Umum Syariah dan 20 Unit Usaha Syariah. Kemudian sampel yang digunakan yaitu rangkuman (ikhtisar) laporan keuangan Perbankan Syariah kurun waktu 3 tahun secara bulanan sehingga jumlah sampel sebanyak $12 \times 3=36$.

Sumber data menggunakan data sekunder mengenai statistik perbankan syariah yang diperoleh melalui website OJK. Teknik analisis yang digunakan adalah analisis jalur (Path Analysis) dengan menggunakan uji t, dimana pengujian mediasi dilakukan dengan prosedur yang dikembangkan oleh Sobel (1982) dan dikenal dengan Uji Sobel (Sobel Test).

\section{HASIL DAN PEMBAHASAN}

Berdasarkan hasil pengolahan data diperoleh hasil sebagai berikut: 
Tabel 1: Rangkuman Hasil Penelitian

\begin{tabular}{|c|c|c|c|c|c|c|c|}
\hline No & \multicolumn{2}{|c|}{ Variabel } & $\begin{array}{l}\text { Direct Efek Coef. } \\
\text { (Standardized) }\end{array}$ & $\begin{array}{l}\text { Unstandardized } \\
\text { Coeficients }\end{array}$ & Std Error & Sig & Keterangan \\
\hline 1 & $\bar{Y}$ & $\bar{Z}$ & 2,837 & 0,154 (b) & $0,047(\mathrm{Sb})$ & 0,002 & Signifikan \\
\hline 2 & $x_{1}$ & Z & $-0,816$ & $-9,929$ & 4,390 & 0,031 & Signifikan \\
\hline 3 & $x_{2}$ & Z & $-1,444$ & $-0,067$ & 0,041 & 0,112 & Tidak Sig. \\
\hline 4 & $X_{1}$ & $\mathrm{Y}$ & 0,058 & 12,937 (a1) & 16,098 (Sa1) & 0,427 & Tidak Sig. \\
\hline 5 & $x_{2}$ & $Y$ & 0,936 & $0,801(\mathrm{a} 2)$ & $0,062(\mathrm{Sa2})$ & 0,000 & Signifikan \\
\hline 6 & $X_{1}$ & $\mathrm{Y}$ & $0,058 * 2,837=$ & & & 0,435 & Tidak Signifikan \\
\hline 7 & $x_{2}$ & Y & $\begin{array}{c}0,936 * 2,837= \\
2,655\end{array}$ & & & 0,001 & $\begin{array}{c}\text { Signifikan } \\
\text { Partial Mediated }\end{array}$ \\
\hline No & & & Regression & & R Square & $\operatorname{Re}$ & ual Coefficient \\
\hline 1 & $X_{1} d$ & $\mathrm{X}_{2} \mathrm{t}$ & (Sub Strukture 1) & & 0,981 & & $0,981=0,138$ \\
\hline 2 & $X_{1}, \lambda$ & dan & Z (Sub Strukture 2) & & 0,552 & & $0,552=0,669$ \\
\hline
\end{tabular}

Sumber: www.ojk.go.id data diolah (2020)

Berdasarkan hasil rangkuman pengolahan data di atas dapat dilakukan analisis sebagai berikut:

\section{Analisis Struktural 1}

Berdasarkan tabel rangkuman hasil penelitian diketahui nilai direct effect coefficients variabel Office Channeling $\left(X_{1}\right)$ sebesar 0,058 yang berarti variabel Office Channeling $\left(X_{1}\right)$ berpengaruh secara langsung terhadap variabel Pembiayaan $(Y)$ sebesar 0,058 . Kemudian nilai direct effect coefficients variabel Dana Pihak Ketiga $\left(X_{2}\right)$ sebesar 0,936 yang berarti variabel Dana Pihak Ketiga $\left(X_{2}\right)$ berpengaruh secara langsung terhadap variabel Pembiayaan (Y) sebesar 0,936.

Besarnya nilai $R$ square sebesar 0,981 hal ini menunjukkan bahwa kontribusi atau sumbangan pengaruh variabel Office Channeling $\left(X_{1}\right)$ dan Dana Pihak Ketiga $\left(X_{2}\right)$ adalah sebesar 98,1\% sementara sisanya 1,9\% merupakan kontribusi dari variabel lain yang tidak dimasukkan dalam penelitian ini.

Berdasarkan hal tersebut diperoleh diagram jalur model struktur 1 sebagai berikut:

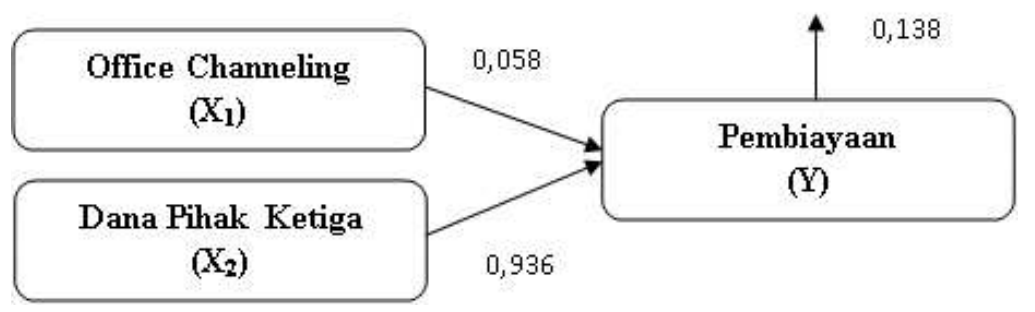

Gambar 1: Diagram Jalur Model Struktural 1 


\section{Analisis Struktural 2}

Berdasarkan tabel rangkuman hasil penelitian diketahui nilai direct effect coefficients variabel yaitu variabel Office Channeling $\left(X_{1}\right)$ sebesar -0,816 yang berarti variabel Office Channeling $\left(\mathrm{X}_{1}\right)$ berpengaruh secara langsung terhadap variabel Laba (Z) sebesar 0,816. Kemudian nilai direct effect coefficients variabel Dana Pihak Ketiga $\left(X_{2}\right)$ sebesar -1,444 yang berarti variabel Dana Pihak Ketiga $\left(X_{2}\right)$ berpengaruh secara langsung terhadap variabel Laba (Z) sebesar 1,444. Selanjutnya nilai direct effect coefficients variabel Pembiayaan $(\mathrm{Y})$ sebesar 2,837 yang berarti variabel Pembiayaan $(\mathrm{Y})$ berpengaruh secara langsung terhadap variabel Laba (Z) sebesar 2,837.

Besarnya nilai $R$ square sebesar 0,552 hal ini menunjukkan bahwa kontribusi atau sumbangan pengaruh variabel Office Channeling $\left(X_{1}\right)$, Dana Pihak Ketiga $\left(X_{2}\right)$ dan Pembiayaan ( $Y$ ) adalah sebesar 55,2\% sementara sisanya 44,8\% merupakan kontribusi dari variabel lain yang tidak dimasukkan dalam penelitian ini.

Berdasarkan hal tersebut diperoleh diagram jalur model struktur 2 sebagai berikut:

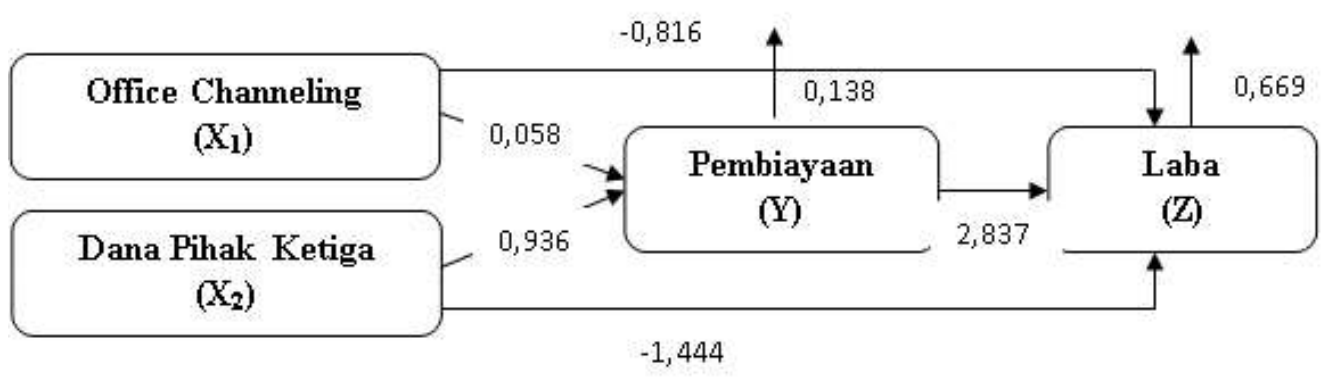

Gambar 2: Diagram Jalur Model Struktural 2

\section{Pengaruh Variabel Office Channeling $\left(\mathrm{X}_{1}\right)$ Terhadap Variabel Pembiayaan $(\mathrm{Y})$}

Berdasarkan hasil perhitungan diperoleh nilai signifikansi variabel Office Channeling $\left(\mathrm{X}_{1}\right)$ sebesar 0,427 > 0,05 yang berarti bahwa Ho diterima dan Ha ditolak artinya variabel Office Channeling $\left(X_{1}\right)$ secara langsung berpengaruh dan tidak signifikan terhadap variabel Pembiayaan $(Y)$. Pengaruh variabel Office Channeling $\left(X_{1}\right)$ secara langsung terhadap variabel Pembiayaan (Y) sebesar 0,058.

Office Channeling tidak memiliki pengaruh yang signifikan terhadap pembiayaan Bank Umum Syariah dan Unit Usaha Syariah, artinya perubahan jumlah office chaneling tidak serta merta dan tidak selalu mengakibatkan perubahan pada pembiayaan. Hal ini dikarenakan Office Channeling merupakan mekanisme kerjasama kegiatan penghimpunan dana antar kantor cabang syariah sebagai kantor induk dengan kantor 
Bank Konvensional bank yang sama dimana dalam kegiatannya hanya penghimpunan dana dalam bentuk giro, tabungan dan deposito tanpa menyalurkannya kepada masyarakat. Penyaluran dana atau pembiayaan kepada masyarakat hanya dilakukan oleh Kantor Induk atau Kantor Cabang.

Hal ini sejalan dengan penelitian Bassar (2005) dimana hasil penelitiannya menunjukkan bahwa kebijakan perbankan 1998 (Bank Konvensional dapat membuka cabang-cabang syariah / office channeling) ternyata hanya berpengaruh terhadap kinerja perbankan dalam menghimpun dana dari masyarakat sedangkan kinerja perbankan dalam menyalurkan dana kepada masyarakat memerlukan factor-faktor lain sebagai penentu .

\section{Pengaruh Variabel Dana Pihak Ketiga $\left(\mathrm{X}_{2}\right)$ Terhadap Variabel Pembiayaan $(\mathrm{Y})$}

Berdasarkan hasil perhitungan diperoleh nilai signifikansi variabel Dana Pihak Ketiga $\left(X_{2}\right)$ sebesar 0,000 < 0,05 yang berarti bahwa Ho ditolak dan Ha diterima artinya variabel Dana Pihak Ketiga $\left(\mathrm{X}_{2}\right)$ secara langsung berpengaruh dan signifikan terhadap variabel Pembiayaan $(Y)$. Pengaruh variabel Dana Pihak Ketiga $\left(X_{2}\right)$ secara langsung terhadap variabel Pembiayaan (Y) sebesar 0,936.

Menurut Nurjaya (2011:65) semakin banyak dana pihak ketiga yang dihimpun, maka akan semakin besar pula tingkat pembiayaan yang akan disalurkan kepada masyarakat. Sebaliknya semakin rendah dana pihak ketiga yang dihimpun maka akan semakin rendah pula tingkat pembiayaan yang disalurkan kepada masyarakat.

Menurut Iska, Syukri (2012) bahwa secara parsial atau individual dana pihak ketiga memberikan pengaruh positif signifikan terhadap pembiayaan perbankan syariah sektor industri. Pada variabel dana pihak ketiga berpengaruh signifikan terhadap pembiayaan perbankan syariah. Artinya semakin tinggi dana pihak ketiga maka semakin tinggi pula pembiayaan perbankan syariah sektor industri. Begitu pula sebaliknya, semakin rendah dana pihak ketiga maka semakin kecil pembiayaan perbankan syariah sektor industri.

Penelitian ini sejalan dengan penelitian yang dilakukan oleh Siti Nurul Kholipah dan Afiati Kurniasih (2017), dimana hasil penelitiannya menunjukkan bahwa dana pihak ketiga berpengaruh signifikan terhadap pembiayaan Perbankan Syariah Sektor Industri di Indonesia.

\section{Pengaruh Variabel Office Channeling $\left(\mathrm{X}_{1}\right)$ Terhadap Variabel Laba (Z)}

Berdasarkan hasil perhitungan diperoleh nilai signifikansi variabel Office Channeling $\left(\mathrm{X}_{1}\right)$ sebesar 0,031 < 0,05 yang berarti bahwa Ho ditolak dan Ha diterima artinya 
variabel Office Channeling $\left(X_{1}\right)$ secara langsung berpengaruh dan signifikan terhadap variabel Laba (Z). Pengaruh variabel Office Channeling $\left(X_{1}\right)$ secara langsung terhadap variabel Laba (Z) sebesar 0,816.

Kebijakan Office Channeling dimaksudkan untuk meningkatkan akses masyarakat kepada jasa perbankan syariah, dengan sistem ini bank syariah tidak perlu membuka kantor cabang syariah baru sehingga biaya ekspansi jauh lebih efisien. Kebijakan ini juga dimaksudkan untuk mengarahkan aktivitas perbankan agar mampu menunjang perekonomian nasional melalui kegiatan perbankan syariah. Tujuan dikeluarkannya Office Channeling adalah dalam rangka mendukung realisasi pencapaian pangsa pasar perbankan syariah. Dengan adanya kebijakan Office Channeling, dana pihak ketiga yang dihimpun bank akan semakin meningkat, sehingga dana yang masuk tersebut akan berputar dan berdampak pada laba bank syariah. Semakin besar dana yang diperoleh bank maka akan semakin besar pula peranan bank syariah terhadap perekonomian indonesia (Syarif, 2010:34).

Penelitian ini sejalan dengan penelitian yang dilakukan oleh Yashinta Putri Aliza dan Eni Wuryani (2019) dimana hasil penelitiannya menunjukkan office channeling berpengaruh negatif terhadap kinerja keuangan Unit Usaha Syariah (UUS) di Indonesia.

\section{Pengaruh Variabel Dana Pihak Ketiga $\left(\mathrm{X}_{2}\right)$ Terhadap Variabel Laba (Z)}

Berdasarkan hasil perhitungan diperoleh nilai signifikansi variabel Dana Pihak Ketiga $\left(\mathrm{X}_{2}\right)$ sebesar 0,112 > 0,05 yang berarti bahwa Ho diterima dan Ha ditolak artinya variabel Dana Pihak Ketiga $\left(X_{2}\right)$ secara langsung berpengaruh dan tidak signifikan terhadap variabel Laba $(Z)$. Pengaruh variabel Dana Pihak Ketiga $\left(X_{2}\right)$ secara langsung terhadap variabel Laba (Z) sebesar 1,444.

Hal ini menunjukkan bahwa semakin besar dana pihak ketiga yang dimiliki suatu bank, belum tentu mencerminkan laba yang besar yang akan diperoleh bank. Hal ini dikarenakan ketidakseimbangan antara jumlah sumber dana yang masuk dengan jumlah kredit yang disalurkan kepada masyarakat. Semakin tinggi dana pihak ketiga yang terkumpul oleh bank namun tidak diimbangi dengan penyaluran kredit, maka kemungkinan bank mengalami kerugian, karena pendapatan bunga dari penyaluran kredit kepada debitur tidak mencukupi untuk menutup biaya bunga yang harus dibayarkan kepada deposan.

Walaupun penghimpunan dana pihak ketiga sudah baik, tetapi tidak diimbangi dengan penyaluran kredit yang deras maka profit/laba bank pun akan terhambat. Hal tersebut dapat terjadi karena alokasi dana yang terhimpun bank belum sepenuhnya dapat dioptimalkan untuk menghasilkan profit/laba bagi bank yang mengakibatkan 
terjadinya pengendapan dana.

Penelitian ini sejalan dengan penelitian yang dilakukan oleh Fauzia (2014) dimana hasil penelitiannya menunjukkan bahwa Dana Pihak Ketiga (DPK) tidak berpengaruh terhadap profitabilitas perusahaan perbankan yang terdaftar di BEI dengan koefisien $\beta$ bernilai negatif sebesar-0,000044 dan nilai signifikansi 0,558 > 0,05.

\section{Pengaruh Variabel Pembiayaan (Y) Terhadap Variabel Laba (Z)}

Berdasarkan hasil perhitungan diperoleh nilai signifikansi variabel Pembiayaan (Y) sebesar 0,002 < 0,05 yang berarti bahwa Ho ditolak dan Ha diterima artinya variabel Pembiayaan $(Y)$ secara langsung berpengaruh dan signifikan terhadap variabel Laba (Z). Pengaruh variabel Pembiayaan (Y) secara langsung terhadap variabel Laba (Z) sebesar $2,837$.

Hasibuan, Malayu S.P (2006:5) menyatakan bahwa penyaluran dana melalui pemberian kredit merupakan usaha yang terpenting bagi bank karena proporsi terbesar dari penyaluran dana yang ada adalah melalui pemberian kredit. Pendapatan yang utama bagi bank adalah usaha yang dilakukan dari kegiatan penyaluran kredit sehingga pada akhirnya akan meningkatkan perolehan laba operasi, yaitu dengan melihat selisih antara biaya yang dikeluarkan untuk mendapat dana operasi bank dengan biaya bunga yang harus ditanggung oleh pihak peminjam sebagai balas jasa atas dana yang diterima.

Ismail (2011) menyatakan bahwa kegiatan penyaluran dana kepada masyarakat merupakan aktivitas yang dapat menghasilkan keuntungan dan memanfaatkan dana bank tertentu yang telah dihimpunnya.

Hasil penelitian ini sejalan dengan penelitian yang dilakukan oleh Annisa Khairani Lubis (2017) dimana hasil penelitiannya menunjukkan bahwa pembiayaan berpengaruh signifikan terhadap laba Bank BNI Syariah.

\section{Pengaruh Variabel Office Channeling $\left(\mathrm{X}_{1}\right)$ Melalui Variabel Pembiayaan ( $\mathrm{Y}$ ) Terhadap Variabel Laba (Z)}

Berdasarkan hasil perhitungan menggunakan Sobel Test diperoleh hasil sebagai berikut: 


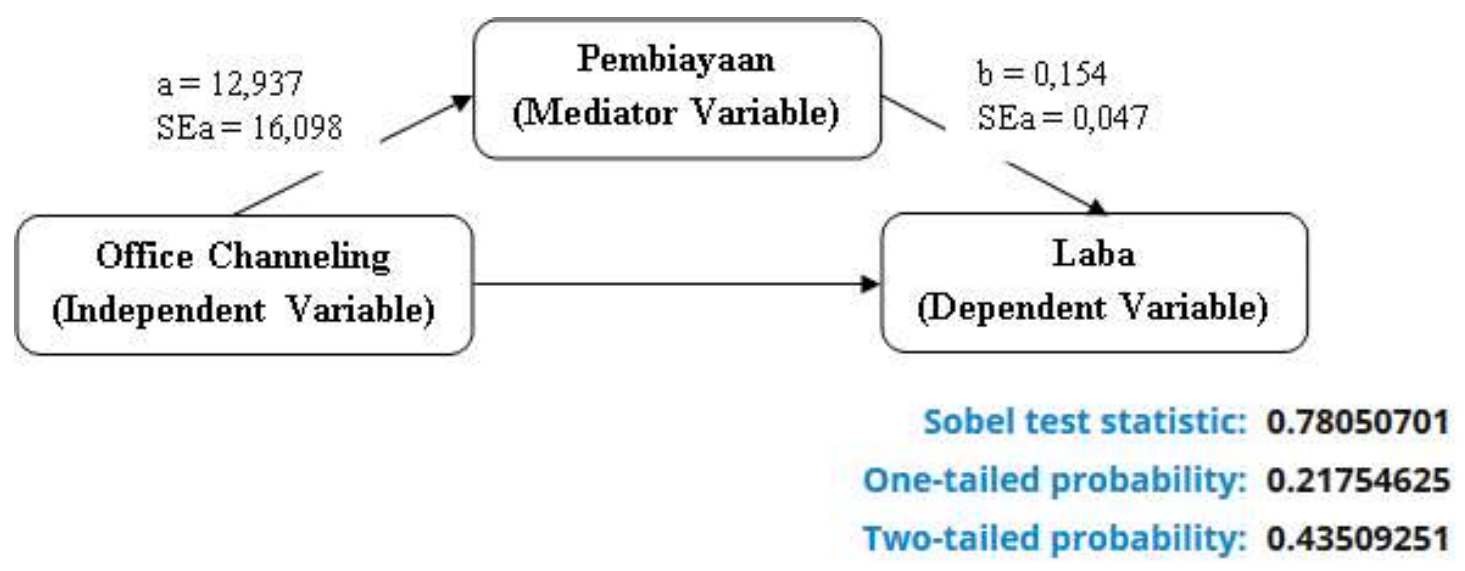

Gambar 3: Hasil Perhitungan Sobel Test Pengaruh $\mathrm{X}_{1}$ Melalui $\mathrm{Y}$ Terhadap $\mathrm{Y}$

Berdasarkan gambar di atas diketahui nilai signifikansi berdasarkan perhitungan sobel test sebesar 0,435 > 0,05 yang berarti bahwa Ho diterima dan Ha ditolak artinya variabel Pembiayaan $(\mathrm{Y})$ tidak mampu memediasi pengaruh variabel Office Channeling $\left(X_{1}\right)$ terhadap variabel Laba $(Z)$. Pengaruh variabel Office Channeling $\left(X_{1}\right)$ secara tidak langsung terhadap variabel Laba ( $Z$ ) melalui variabel Pembiayaan ( $Y$ ) sebesar 0,165 .

Office channeling hanya melakukan kegiatan penghimpunan dana namun tidak menyalurkan kembali dana tersebut dalam bentuk pembiayaan kepada masyarakat. Penyaluran pembiayaan dapat dilakukan oleh kantor induknya yaitu Kantor Cabang Syariah (KCS). Sedangkan pembiayaan merupakan sumber utama pendapatan dalam menghasilkan laba pada suatu bank yang dimana pembiayaan tesebut telah disalurkan kepada masyarakat, yang mana penyaluran pembiayaan akan dilakukan di Kantor Cabang Syariah (KCS) bukan pada layanan Office Channeling.

\section{Pengaruh Variabel Dana Pihak Ketiga $\left(\mathrm{X}_{2}\right)$ Melalui Variabel Pembiayaan (Y) Terhadap Variabel Laba (Z) \\ Berdasarkan hasil perhitungan menggunakan Sobel Test diperoleh hasil sebagai berikut:}




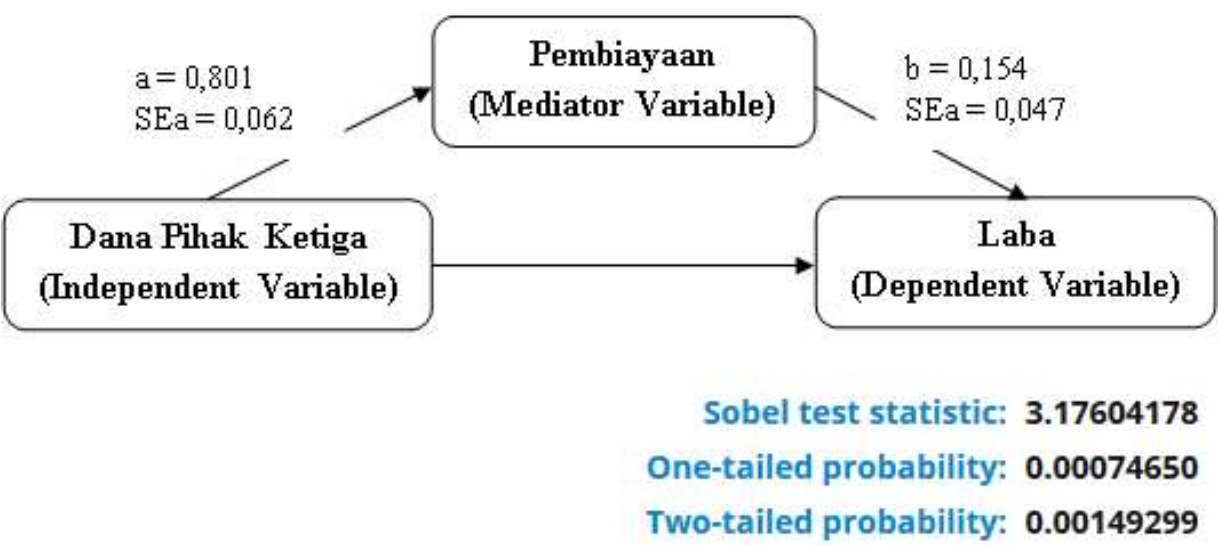

Gambar 4: Hasil Perhitungan Sobel Test Pengaruh $X_{2}$ Melalui $Y$ Terhadap $Y$

Berdasarkan gambar di atas diketahui nilai signifikansi berdasarkan perhitungan sobel test sebesar 0,001 yang berarti bahwa Ho ditolak dan Ha diterima artinya variabel Pembiayaan ( $\mathrm{Y}$ ) mampu memediasi pengaruh variabel Dana Pihak Ketiga $\left(\mathrm{X}_{2}\right)$ terhadap variabel Laba $(Z)$. Pengaruh variabel Dana Pihak Ketiga $\left(X_{2}\right)$ secara tidak langsung terhadap variabel Laba (Z) melalui variabel Pembiayaan (Y) sebesar 2,655.

Hubungan antara Dana Pihak Ketiga (DPK) dengan pembiayaan perbankan syariah adalah positif. Hubungan yang positif ini dikarenakan Dana Pihak Ketiga merupakan sumber pendanaan perbankan syariah yang paling utama, semakin besar jumlah Dana Pihak Ketiga (DPK) yang dihimpun oleh perbankan syariah dari masyarakat maka semakin besar pula pembiayaan yang akan diberikan oleh perbankan syariah kepada masyarakat. Dalam menjalankan fungsi intermediasi, perbankan syariah mengoptimalkan dana yang dihimpun dari masyarakat untuk dialokasikan dalam bentuk pembiayaan, mengingat dana pihak ketiga merupakan faktor yang dominan dalam besarnya pembiayaan yang diberikan oleh perbankan syariah kepada masyarakat yang berdampak pada peningkatan laba.

\section{SIMPULAN}

1. Nilai signifikansi variabel Office Channeling $\left(X_{1}\right)$ sebesar 0,427 lebih besar dari 0,05 yang berarti variabel Office Channeling $\left(X_{1}\right)$ secara langsung berpengaruh dan tidak signifikan terhadap variabel Pembiayaan $(Y)$. Pengaruh variabel Office Channeling $\left(X_{1}\right)$ secara langsung terhadap variabel Pembiayaan $(Y)$ sebesar 0,058 .

2. Nilai signifikansi variabel Dana Pihak Ketiga $\left(X_{2}\right)$ sebesar $0,000<0,05$ yang berarti bahwa variabel Dana Pihak Ketiga $\left(\mathrm{X}_{2}\right)$ secara langsung berpengaruh dan signifikan terhadap variabel Pembiayaan ( $Y$ ). Pengaruh variabel Dana Pihak Ketiga $\left(\mathrm{X}_{2}\right)$ secara langsung terhadap variabel Pembiayaan $(\mathrm{Y})$ sebesar 0,936 . 
3. Nilai signifikansi variabel Office Channeling $\left(X_{1}\right)$ sebesar $0,031<0,05$ yang berarti bahwa variabel Office Channeling $\left(X_{1}\right)$ secara langsung berpengaruh dan signifikan terhadap variabel Laba (Z). Pengaruh variabel Office Channeling $\left(X_{1}\right)$ secara langsung terhadap variabel Laba $(Z)$ sebesar 0,816 .

4. Nilai signifikansi variabel Dana Pihak Ketiga $\left(X_{2}\right)$ sebesar 0,112 >0,05 yang berarti bahwa variabel Dana Pihak Ketiga $\left(X_{2}\right)$ secara langsung berpengaruh dan tidak signifikan terhadap variabel Laba (Z). Pengaruh variabel Dana Pihak Ketiga $\left(X_{2}\right)$ secara langsung terhadap variabel Laba $(Z)$ sebesar 1,444 .

5. Nilai signifikansi variabel Pembiayaan $(\mathrm{Y})$ sebesar $0,002<0,05$ yang berarti bahwa variabel Pembiayaan $(Y)$ secara langsung berpengaruh dan signifikan terhadap variabel Laba $(Z)$. Pengaruh variabel Pembiayaan $(Y)$ secara langsung terhadap variabel Laba (Z) sebesar 2,837.

6. Nilai signifikansi berdasarkan perhitungan sobel test sebesar 0,435 > 0,05 yang berarti bahwa variabel Pembiayaan $(Y)$ tidak mampu memediasi pengaruh variabel Office Channeling $\left(X_{1}\right)$ terhadap variabel Laba $(Z)$. Pengaruh variabel Office Channeling $\left(X_{1}\right)$ secara tidak langsung terhadap variabel Laba (Z) melalui variabel Pembiayaan $(Y)$ sebesar 0,165.

7. Nilai signifikansi berdasarkan perhitungan sobel test sebesar 0,001 yang berarti bahwa variabel Pembiayaan ( $Y$ ) mampu memediasi pengaruh variabel Dana Pihak Ketiga $\left(X_{2}\right)$ terhadap variabel Laba $(Z)$. Pengaruh variabel Dana Pihak Ketiga $\left(\mathrm{X}_{2}\right)$ secara tidak langsung terhadap variabel Laba (Z) melalui variabel Pembiayaan $(Y)$ sebesar 2,655.

\section{PUSTAKA ACUAN}

Aam Slamet Rusydiana. 2016. Analisis Masalah Pengembangan Perbankan Syariah di Indonesia: Aplikasi Metode Analytic Network Process. Jurnal Bisnis dan Manajemen Volume 6 (2), Oktober 2016

Annisa Khairani Lubis. 2017. Pengaruh Dana Pihak Ketiga, Pembiayaan dan Modal Terhadap Laba Pada PT BNI Syariah. Skripsi Fakultas Ekonomi dan Bisnis Islam UIN Sumatera Utara Medan.

Bassar, Teddy, Sumirat. (2005). Dampak Kebijakan Perbankan 1998 Terhadap Kinerja Penghimpunan dan Penyaluran Dana Masyarakat pada Bank Syariah (Shri Kasus pada PT. Bank Muamalat Indonesia. Juntal Ekonomi Keuangan dan Bisnis Islam Universitas Indonesia.

Binti Nur Asiyah. 2014. Manajemen Pembiayaan Bank Syariah. Yogyakarta: Teras Dendawijaya. 2009. Manajemen Perbankan. Edisi Revisi Sembilan.

Fauzia. 2014. Pengaruh Dana Pihak Ketiga (DPK), Non Performing Loan (NPL), dan 
Biaya Operasional Pendapatan Operasional (BOPO) Terhadap Profitabilitas (Studi empiris Pada Perusahaan Perbankan Yang Terdaftardi Bursa Efek Indonesia Tahun 2009 -2013). Fakultas Ekonomi Universitas Negeri Padang

Fitri. 2014. Beberapa Permasalahan Perbankan Syariah di Indonesia.

Hasibuan, SP Malayu. 2006. Manajemen Perbankan. Jakarta: Ghalia Indonesia.

Iska, Syukri, 2012. Sistem Perbankan Syariah Di Indonesia dalam Perspektif Fikih Ekonomi, Yogyakarta : Fajar Media Press.

Ismail. 2011. Manajemen Perbankan dari Teori Menjadi Aplikasi. Jakarta: Kencana Prenada Media Group.

Jumingan. 2011. Analisis Laporan Keuangan Jakarta: PT Bumi Aksara

Luhur Prasetiyo. 2012. Perkembangan Bank Syariah Pasca UU 21 Tahun 2008. Jurnal Al-Tahrir, Vol. 12, No. 1 Mei $2012: 43-63$

Muhammad. 2008. Manajemen Pembiayaan Bank Syariah. Edisi Kedua. UPP STIM YKPN Yogyakarta.

Nurjaya, Endang. 2011. Analisis Pengaruh Inflasi Sertifikat Bank Indonesia Syariah (SBIS), Non Performing Financing (NPF) dan Dana Pihak Ketiga (DPK) terhadap pembiayaan murabahah pada Bank Syariah di Indonesia (Periode Januari:2007-Maret: 2011).

Peraturan Bank Indonesia (PBI) No. 9/7/PBI/2007 tanggal 4 Mei 2007 tentang Perubahan Atas Peraturan Kegiatan Usaha Bank Umum Konvensional Menjadi Bank Umum yang Melaksanakan Kegiatan Usaha Berdasarkan Prinsip Syariah dan Pembukaan Kantor Bank yang Melaksanakan Kegiatan Usaha Berdasarkan Prinsip Syariah oleh Bank Umum Konvensional

Peraturan Bank Indonesia (PBI) No.8/3/2006 tentang Layanan Syariah

Siti Nurul Kholipah dan Afiati Kurniasih. 2017. Faktor-Faktor Yang Mempengaruhi Pembiayaan Perbankan Syariah Sektor Industri Di Indonesia. Jurnal Nisbah Vol. 3 No. 1 Tahun 2017.

Syarif, Muhammad. 2010. "Penerapan Offie Channeling Pada Bank Syariah" (Skripsi Program Studi Ekonomi Islam, UIN Sultan Syarif Kasim, Riau, 2010), h. 34-35

Undang - Undang No. 10 tahun 1998 Tentang Perbankan

Undang-Undang Nomor 10 Tahun 1998 tentang Perbankan

Yashinta Putri Aliza dan Eni Wuryani. 2019. Dampak Layanan Syariah (Office Channeling) Terhadap Pertumbuhan Aset, Kenaikan Dana Pihak Ketiga (DPK), dan Kinerja Keuangan Pada Unit Usaha Syariah (UUS) Tahun 20122016. Jurusan Akuntansi, Fakultas Ekonomi,Universitas Negeri Surabaya 